\title{
Estatuto ontológico da contradição interna do Algo
}

\author{
Emmanuel Zenryo Chaves Nakamura ${ }^{1}$
}

\begin{abstract}
RESUMO: Este trabalho tem como objetivo analisar o estatuto ontológico da noção de contradição interna na dialética do Algo e do Outro, presente no capítulo "O Ser-aí" da Ciência da Lógica de Hegel, ressaltando como essa dialética ressoa no capítulo "A Mercadoria" de Para a Crítica da Economia Política de Marx. A hipótese é que a "dessublimação da filosofia" operada por Marx não é estranha à Lógica hegeliana, estando em curso no seu próprio projeto.
\end{abstract}

Palavras-chave: Hegel; Marx; Contradição; Ser-aí; Mercadoria

ABSTRACT: This paper analyzes the ontological status of the concept of internal contradiction in the dialectic of Something and the Other, in the chapter "Determinate Being" from Hegel's Science of Logic, emphasizing how this dialectic resonates in the chapters "The Commodity" A Contribution to the Critique of Political Economy, from Marx. The hypothesis is that the "de-sublimation of philosophy" operated by Marx is no stranger to the Hegelian Logic, being under way in its own project.

Key-words: Hegel; Marx; Contradiction; Determinate Being; Commodity

O professor não podia comparar-se aos viventes comuns. Grave, o dedo na página, articulara: Smailes. Nas lições seguintes percebi que ele não se contradizia. Comecei então a admirá-lo. Procurei outras palavras em que o $i$ se pronunciasse daquele jeito. Inutilmente. Apesar de tudo Smiles era Smailes, e ninguém me tirava daí.

Graciliano Ramos $^{2}$

\section{Introdução}

Começo com essa citação de Graciliano Ramos rememorando a sua infância apenas com o intuito de ressaltar a "admiração àquele homem que alterava as letras", o seu professor. Talvez, ela nos ajude a remeter à essência da relação da dialética

\footnotetext{
${ }^{1}$ Graduado em Economia pela PUC-SP e mestrando em Filosofia pelo Programa de Pós-Graduação em Filosofia do Instituto de Filosofia e Ciências Humanas da UNICAMP. Artigo submetido para avaliação em 27 de outubro de 2009.

${ }^{2}$ Infância. 1. ed. Rio de Janeiro: MEDIAFashion, 2008. (Coleção Folha Grandes Escritores Brasileiros; v. 16). p. 175.
} 
especulativa com a linguagem. Para Hegel, as "formas-do-pensar são expostas (herausgesetzt) e depositam-se em primeiro lugar na linguagem do homem"”3. Para ele, é vantagem de uma língua "se possui uma riqueza de expressões lógicas, a saber (nämlich), particulares e separadas, para as determinações do pensar" (WdL. I, p. 20). Entre as línguas modernas, a língua alemã tem uma vantagem particular de ter palavras não só com significados diferentes, mas também opostos, o que expressa o "espírito especulativo da língua". Encontrar nas palavras a unificação dos opostos, realizada ainda que de modo ingênuo, lexicalmente, como uma palavra de significados opostos, pode proporcionar uma alegria ao pensamento especulativo, no entanto, para o entendimento, nada mais é que um contra-senso (widersinnig) (WdL. I, pp. 20-1).

Com esse "contra-senso", entramos propriamente no tema deste trabalho. "Contra-senso", na tradição dialética moderna, tem nome próprio, a saber, contradição (Widerspruch). O objetivo deste trabalho é analisar o estatuto ontológico da noção de "contradição interna" na dialética do Algo e do Outro, presente no capítulo "O Ser-aí" da Ciência da Lógica de Hegel, ressaltando como essa dialética ressoa no capítulo "A Mercadoria" de Para a Crítica da Economia Política de Marx. A hipótese é que a "dessublimação da filosofia", operada por Marx não é estranha à Lógica hegeliana, estando em curso no seu próprio projeto.

O segundo capítulo da Ciência da Lógica, "O Ser-aí”, apresenta a primeira aparição da "contradição interna". Adiantando o problema, a partir da Enciclopédia, quando a natureza do finito é expressa no Algo, esse não se defronta indiferentemente com o Outro, "mas é em si Outro de si mesmo, e por isso se altera. Na alteração, mostra-se a contradição interior, de que o ser-aí (Dasein) é afetado desde a origem, e que o impele para além de si mesmo" ${ }^{5}$. O capítulo 1 de Para a Crítica da Economia

\footnotetext{
${ }^{3}$ HEGEL, G. W. F. Wissenschaft der Logik I. Erster Teil: Die objektive Logik. Erstes Buch. Werke in zwanzig Bänden. Edição de E. Moldenhauer e K. M. Michel. Frankfurt am Main: Suhrkamp, 1986. v. 5. p. 20. Doravante citado WdL. I.

4 “(...) E se fosse o contrário? Isto é, se estivesse na Crítica da Economia Política a chave explicativa dos teoremas filosóficos mais enfáticos, não um achatamento positivista, mas uma identificação do seu verdadeiro assunto. Veja-se o caso da especulação hegeliana: não se deveria procurar no fenômeno histórico do fetichismo da mercadoria a solução enigmática da desenvoltura ontológica do Conceito? Mas àquela altura de nossa linha evolutiva não ocorria a ninguém essa espécie de dessublimação da filosofia". Cf. ARANTES, P. E. Um Departamento francês de ultramar: Estudos sobre a formação da cultura filosófica uspiana (Uma experiência nos anos 60). São Paulo: Paz e Terra, 1994. pp. 250-1.

${ }^{5}$ HEGEL, G. W. F. Enzyklopädie der philosophischen Wissenschaften im Grundrisse (1830). Erster Teil: Die Wissenschaft der Logik mit den mündlichen Zusätzen. Werke in zwanzig Bänden. Edição de E. Moldenhauer e K. M. Michel. Frankfurt am Main: Suhrkamp, 1986. v. 8. § 92, Zusatz, p. 198. Doravante
} 
Política, "A Mercadoria”, parece ser o correspondente lógico na Darstellung marxiana do sistema capitalista. Apenas com caráter ainda ilustrativo, podemos aqui lembrar a maneira como Marx começa esse capítulo: "A primeira vista, a riqueza burguesa aparece como uma monstruosa (ungeheure) coleção de mercadorias, e a mercadoria isolada como seu ser-aí elementar"6.

A análise da dialética marxiana se limitará ao capítulo primeiro de Para a Crítica da Economia Política e não abordará a apresentação d'O Capital. Isso porque, em razão dos limites externos contingentes que envolvem o presente trabalho, a obra de 1859, talvez nos permita contrapor de maneira mais fácil as duas dialéticas, por utilizar abertamente os "modos próprios de expressão" da dialética hegeliana, como escreveu o próprio Marx no Prefácio d'O Capital de 24 de janeiro de 1873. No entanto, e aqui justificamos melhor a hipótese deste trabalho, tentaremos esboçar uma crítica da visão da dialética, seja ela hegeliana ou marxista, como mera "façon de parler"7. Para isso, tentaremos aproximar o ponto de vista do qual ambos, Hegel e Marx, escrevem, através de uma reflexão sobre os Prefácios de 1812 e 1831 à Ciência da Lógica - nos quais Hegel apresenta a tarefa da lógica, qual seja, de "trazer à consciência esta natureza lógica que anima o espírito, que nele impulsiona e efetua" (WdL. I, p. 27) -, a partir de algumas considerações de P. Arantes em Hegel: ordem do tempo. Essa reflexão nos permitirá, talvez, compreender a relação entre a dialética presente no ser-aí e na

citado Enzy. I. Tradução de Paulo Meneses. Enciclopédia das ciências filosóficas em compêndio (1830). Volume I: A Ciência da Lógica. São Paulo: Loyola, 1995. (coleção O Pensamento Ocidental). p. 189.

${ }^{6}$ MARX, K. Zur Kritik der Politischen Ökonomie. Karl Marx Friedrich Engels Gesamtausgabe (MEGA). Zweite Abteilung, Band 2. Berlim: Dietz Verlag, 1980. pp. 95-245. p. 107. Doravante citado Zur Kr. Tradução de Edgard Malagodi. Para a Crítica da Economia Política. In: Karl Marx. São Paulo: Nova Cultural, 1999. pp. 22-186. (coleção Os Pensadores). p. 57. (grifo nosso). A análise se limitará à contraposição lógica entre ser-aí e mercadoria, não abordando a dialética fenomenológica, também presente na dedução da forma valor, como bem salientou M. Müller: "Não é só a dialética lógica, própria da exposição do auto-movimento do conceito na Ciência da Lógica, que atua no texto e na arquitetônica d'O Capital, mas, também, a dialética fenomenológica, exposta por HEGEL na Fenomenologia do Espírito, como por exemplo no Livro I, capítulo 1, d'O Capital, a propósito da dedução da forma valor e do ponto de partida com a mercadoria, como um imediato também fenomenológico, e não só lógico (...)”. MÜLLER, M. L. Exposição e método dialético em 'O Capital'. Boletim SEAF (Sociedade de Estudos e Atividades Filosóficas). Belo Horizonte, n. 2, pp. 17-41, 1982. p. 18.

${ }^{7}$ Esse esboço crítico tem como referência menos a obra de G. Lebrun sobre o "discurso dialético", e sim mais um artigo de J. A. Giannotti intitulado "Dialética futurista e outras demãos". Escreve ele: "Escolher entre lógica formal e lógica dialética vem a ser um processo baseado numa observação, em vez de ser uma questão relativa ao sentido das proposições e da linguagem - vale dizer, uma questão transcendental. Mas a solução engelsiana está cometendo o engano de tomar como contraditórias afirmações contrárias feitas de sentidos diversos. O que os pode unir numa óptica a fim de que sejam de fato contraditórias?" Cf. GIANNOTTI, J. A. Dialética futurista e outras demãos. Novos Estudos CEBRAP, São Paulo, n. 57, pp. 59-79, Jul. 2000a. Disponível em: <http://novosestudos.uol.com.br〉. Acesso em: 4 jan. 2008. p. 65. 
mercadoria não como uma simples analogia, mas sim como "método de apresentação" marxiano, no qual a função paradigmática da dialética hegeliana constituiria em

antecipar em sua estrutura lógica especulativa estruturas racionais que Marx, em sua análise do capitalismo, reconheceu como exprimindo de maneira críptica algumas dimensões econômicas fundamentais da sociedade burguesa dominada pela relação capitalista de produção (MÜLLER, 1982, p. 31).

\section{Algo e Outro, a Finitude}

O capítulo "O Ser-aí" (Das Dasein) da Ciência da Lógica é dividido em três partes: "A. o ser-aí como tal"; "B. Algo e Outro, a Finitude"; e "C. o infinito qualitativo" (WdL. I, p. 115). Neste item apresentaremos de maneira sintética as duas primeiras partes, deixando a última para o item seguinte.

O ser-aí como tal é, em primeiro lugar, sua determinidade (Bestimmtheit). O ser-aí provém (hervorgeht) do devir (Werden), e por isso é simples ser-uno do ser e do nada. É simples porque tem ainda a forma de um imediato. Não é puro ser, mas ser-aí, ser em um lugar. A unidade imediata entre ser e nada constitui (ausmacht) a sua determinidade (WdL. I, p. 116). Nessa imediaticidade, a determinidade é isolada, como determinidade sendo, é a Qualidade, um todo simples, imediato (WdL. I, p. 118).

No entanto, o ser-aí é unidade imediata do ser e do nada. Se, por um lado, a qualidade é posta como determinidade sendo, por outro lado, ela tem que ser posta também na determinação (Bestimmung) do nada. O nada como o determinado de uma determinidade é um refletido, uma negação (Verneinung). A qualidade que vale distintamente como sendo é a realidade (Realität), mas, como é afetada por uma negação (Verneinung), é uma negação em geral (Negation überhaupt); é igualmente uma qualidade, mas vale como falta (Mangel) - determinada mais adiante como limite (Grenze), barreira (Schranke) (WdL. I, p. 118).

Com isso, as diferenças (Unterschiede) são no (an dem) ser-aí aí-presentes (vorhanden), como nulas e suspensas (aufgehoben), pois ambos, realidade e negação (Negation), são ser-aí, e não um ser indeterminado, abstrato. A qualidade em geral não é separada do ser-aí, pois o que está aí-presente é o ser-aí em geral (Dasein überhaupt), portanto, a suspensão das diferenças é uma determinidade do ser-aí. Assim, esse é um 
Ser-dentro-de-si (Insichsein), o ser-aí é sendo-aí (Daseiendes), Algo (Etwas) (WdL. I, pp. 122-3).

O Algo é a primeira negação da negação como sendo simples relação (Beziehung) consigo (auf sich). Ele é o começo do sujeito, mas só o começo, pois o Serdentro-de-si é ainda totalmente indeterminado. Sua mediação consigo, a qual em si (an sich) é o Algo, é só a negação da negação, sem determinação (Bestimmungen) concreta. Assim, o Algo cai junto na unidade simples do ser, ou seja: "Algo é e é, pois, também sendo-aí" (WdL. I, p. 124). No entanto, ele é em si, além disso, também Devir, mas não mais só como momento do ser e do nada. Isso porque se o ser é ser-aí, depois sendo-aí Algo, o nada é, do mesmo modo, sendo-aí, mas como negativo do Algo determinado, como um Outro (Anderes). Assim, o Devir torna-se passagem (Übergehen), na qual seus momentos são Algo mesmo e, por isso, ela é alteração (Veränderung). No entanto, Algo se mantém só como em si em sua simples relação consigo e seu negativo é igualmente (ebenso) qualitativo, isto é, um Outro em geral (überhaupt) (WdL. I, p. 124).

Nessa igualdade qualitativa, Algo e Outro são ambos, primeiramente, sendo-aí ou Algo, mas, do mesmo modo, ambos são Outro. Só através de um designar (Bezeichnen) subjetivo é possível fixar a diferença do Algo, ou seja, só através de um Isto (Dieses), mas, assim, nesse mostrar exterior cai toda determinidade, pois a expressão Isto não contém nenhuma diferença. Entre eles não há diferenças aí-presentes e esta mesmidade da determinação cai, portanto, só na reflexão exterior, na comparação entre ambos (WdL. I, p. 126).

No entanto, o Outro está posto em primeiro lugar (zunächst), pois ao se determinar cada ser-aí se determina outro ser-aí, de modo que não permanece um ser-aí determinado, como um ser-aí fora do outro. Assim, o Outro está por si (für sich) em relação com Algo, mas também por si fora do mesmo (WdL. I, p. 126). O Outro é por si o Outro nele mesmo (an ihm selbst), o Outro de si mesmo, o Outro do Outro, portanto, o puro e simplesmente desigual dentro de si, que se nega e se altera a si mesmo, coincidindo consigo mesmo. Assim, ele é posto como refletido dentro de si mesmo através do suspender (Aufheben) do Ser-outro, e, com isso, como Algo idêntico consigo, ou seja, é o Algo que se conserva no seu não-ser-aí (Nichtdasein) (WdL. I, p. 127). Algo, então, é e não é essencialmente uno com o seu Ser-outro. Ele está dentro da relação com o seu ser e seu Ser-outro, ou seja, não é puramente seu Ser-outro, pois esse 
está contido e, ao mesmo tempo (zugleich), separado dele, isto é, Algo é Ser-para-outro (Sein-für-Anderes) (WdL. I, p. 127). Mas Algo se conserva no seu não-ser-aí, e não no seu não-ser em geral, portanto, se conserva na sua relação consigo contra sua relação com Outro, como igualdade consigo contra sua desigualdade. Assim, é também Ser-emsi (Ansichsein) (WdL. I, p. 128).

Ser-para-outro e Ser-em-si constituem (ausmachen) dois momentos do Algo e a verdade do Algo e do Outro, pois esses ainda caem um fora do outro (auseinander), mas a verdade deles é a relação na qual ambos são determinações (Bestimmungen) postas como um momento mesmo, ou seja, cada um fica na unidade do ser-aí, contendo nele, ao mesmo tempo, o seu momento diferente (verschiedenes) (WdL. I, p. 128).

Assim, o Ser-em-si é, primeiramente, relação negativa com o seu não-ser, tem o Ser-outro fora de si e como oposto, ou seja, Algo em-si retira (entnommen) de si o Ser-outro e o Ser-para-outro, mas, em segundo lugar, tem também o não-ser nele mesmo, pois é ele mesmo o não-ser do Ser-para-outro. Inversamente (umgekehrt), o Ser-para-outro é, primeiramente, negação da simples relação do ser consigo, na qual ser-aí e Algo devem ser (soll sein) em primeiro lugar, mas Algo é dentro de um Outro ou para um Outro, ou seja, falta-lhe o ser próprio. No entanto, em segundo lugar, Serpara-outro é o não-ser-aí do Ser-em-si como seu ser dentro de si refletido (WdL. I, pp. 128-9). Nisso pode se notar o que é a chamada coisa-em-si (Dings-an-sich), uma simples abstração, ou seja, chama-se uma coisa de em si quando se abstrai dela todo o Ser-para-outro, toda a determinação, isto é, quando ela é pensada como nada (cf. $W d L$. I, pp. 129-30). No entanto, o Ser-para-outro é, na unidade do Algo consigo, idêntico com o seu em-si, ou seja, ele é no (am) Algo, que dentro de si é determinidade (Bestimmtheit) refletida, e, com isso, de novo simplesmente sendo, por conseguinte, uma nova qualidade, a determinação (Bestimmung) (WdL. I, p. 131).

A determinação é a qualidade que é em-si (Ansich) no simples Algo essencialmente (wesentlich) na unidade com o seu outro momento, o ser-nele (An-ihmSein). Ela é diferente da determinidade (Bestimmtheit), pois é a afirmação dessa como Ser-em-si que se conserva na sua unidade consigo, que se faz válido (macht geltend) no seu Ser-para-outro (WdL. I, p. 132). Assim, o Ser-em-si se preenche com a determinidade, mas ele é diferente dessa, que é só um Ser-para-outro e fica fora da determinação, pois, no campo das qualidades, as diferenças permanecem no seu ser- 
suspenso ainda imediatas, o ser qualitativo contra o outro. Desse modo, o que o Algo tem nele se divide: a determinidade é o ser-aí do Algo, mas não lhe pertence, e, por isso, ela é disposição (Beschaffenheit) (WdL. I, p. 133). Determinação e disposição são, então, distintos um do outro, pois Algo é sua determinação para sua igualdade contra sua disposição. No entanto, Algo tem nele (an ihm) o meio-termo dos dois extremos deste silogismo (Schlusses), qual seja, a determinidade como tal que na sua identidade pertence tanto à determinação quanto à disposição. Assim, a determinidade é momento que contém a diferença qualitativa, um outro ser-aí, ou seja, contém o negativo do Algo, o diferente do Ser-em-si. Ela traz, portanto, o Ser-outro dentro do Ser-em-si, isto é, como sua determinação, a qual é, portanto, reduzida à disposição. Inversamente, o Serpara-outro isolado como disposição e posto por si é Outro nele mesmo. Ele é ser-aí que se relaciona consigo mesmo, portanto, tem uma determinidade no seu Ser-em-si, ou seja, é determinação (WdL. I, p. 134). A disposição, então, depende da determinação, apesar deles se manterem exterior um ao outro, e a disposição aparecer fundada (gegründet erscheint) num Outro geral exterior. O determinar estranho (fremde) é, através dele próprio, imanente ao Algo, com isso, a disposição pertence ao que o Algo é em si: Algo se altera com sua disposição (WdL. I, p. 134). A alteração é, então, posta no $\operatorname{Algo~(WdL.~I,~p.~134).~}$

Essa passagem (Übergehen) da determinação e da disposição, uma na outra, é o suspender (Aufheben) das suas diferenças. O ser-aí ou o Algo em geral são postos e a diferença entre eles inclui dentro deles o Ser-outro, por isso a negação torna-se imanente ao Algo. Ambos são sendo-aí indiferentes um ao outro, mas não se afirmam imediatamente, mas sim referem-se a si mesmo mediante o suspender do Ser-outro, o qual é refletido na determinação no Ser-em-si (WdL. I, pp. 134-5). Com isso, o Serdentro-de-si (Insichsein) do Algo contém a negação dentro de si, tendo o Algo, através dessa mediação geral, o seu ser-aí afirmativo. A negação do seu Outro é a qualidade do Algo, ou seja, Algo é nesse suspender do seu Outro. O Ser-dentro-de-si do Algo é o não-ser do Outro. Esse é a negação da negação no Ser-em-si do Algo. Nesse suspender como simples negação nele, Algo nega nele outro Algo externo. Algo e Outro têm uma determinidade, a qual tanto é idêntica com o Ser-dentro-de-si do Algo como negação da negação, como também estão separados, Algo e Outro, encadeados (zusammenschließt) um contra o outro. Essa determinidade é, portanto, o limite (Grenze) (WdL. I., p. 135). 
Esse limite é imanente ao Algo e é sua contradição mesma, a qual o dirige e o impulsiona para fora de si. Com isso, chegamos ao finito (WdL. I, p. 139).

O finito é a negação qualitativa impulsionada ao seu extremo (Spitze). Ele é esta simplicidade qualitativa da negação que volta à oposição abstrata do nada e do perecer (Vergehens), por isso é uma categoria do entendimento (Verstandes), pois é a negação em si fixada e por isso está em rude (schroff) contraste com sua afirmação. A determinação das coisas é no seu fim, mas, ao persistir (verharrt) na finitude, o entendimento faz dela imperecível e absoluto. O perecer se torna o último e não se passa no afirmativo, através do qual o perecer perece. Por outro lado, ao infinito é atribuído (zugeschrieben) o ser absoluto, mas o finito fica do seu lado como também um absoluto, impossível de se unificar com o finito (WdL. I, pp. 140-1).

No entanto, Algo não é mais posto abstratamente, mas é dentro de si refletido e desenvolvido como Ser-dentro-de-si que tem determinação, disposição e um limite nele imanente, constituindo, a finitude, a qualidade do Ser-dentro-de-si (WdL. I, p. 142). Assim, o limite próprio ao Algo é essencialmente posto nesse como um negativo não só como limite enquanto tal, mas como barreira (Schranke). O limite é tanto a determinidade do Ser-dentro-de-si do Algo e do Outro como negação da negação, como também deles separados por meio dessa negação. A barreira é a relação negativa do Serem-si com o limite diferente dele. Ela é, assim, o dever (Sollen) (WdL. I, pp. 142-3). Ou seja, o limite se torna barreira na qual Algo sai de si mesmo quando suspende seu Serem-si negativo (WdL. I, p. 143).

O dever contém, portanto, duas determinações: uma vez como sendo em si determinação contra a negação, e outra vez como não-ser que é barreira diferente dele, mas que é, ao mesmo tempo, determinação sendo-em-si mesma. Dever e barreira são, ambos, momentos do finito, mas enquanto a barreira é posta como finita, o dever é só em si, ou seja, sua limitação (Beschränkung) é no Ser-em-si embrulhada (eingehüllt). Por isso, o que deve ser é e não é ao mesmo tempo. O dever tem essencialmente uma barreira que é determinação posta de fato só como uma determinidade (WdL. I, pp. 1434). No entanto, dever e barreira são idênticos, pois, através do dever, o Ser-em-si é considerado como não-ser, isto é, sua determinação é não-ser, mas seu Outro é outro limite qualitativo, e, com isso, seu limite não é um limite, mas uma barreira sobre a qual se ergue. Ambos são, por isso, inseparáveis (WdL. I, p. 144). 
Assim, o dever por si contém a barreira e essa, o dever. A relação de um com o outro é o finito que ambos contêm no seu Ser-dentro-de-si. Ambos são momentos do finito e são determinados como o negativo do outro. O finito é a contradição sua em si, o que se suspende a si mesmo e o que perece, mas, com isso, como resultado de sua determinação, a negação da negação, obtém só o negativo em geral, o que é outro finito, isto é, seu perecer é passagem para outro finito e assim segue ao infinito. Nisso o finito coincide consigo mesmo, mas esse mais além ou seu Outro é só a barreira mesmo, mas essa indica sobre si mesma o seu Outro imediatamente além, o que é o dever. Isso nada mais é do que a desavença (Entzweiung) do Ser-em-si e do ser-aí como barreira. Essa, indo além de si, coincide consigo mesma e assim segue ao infinito (WdL. I, pp. 148-9).

\section{O mau infinito e a infinitude verdadeira}

Ir além de si mesmo, negar a sua negação e com isso tornar-se (werden) infinito é a natureza mesma do finito, ou seja, a infinitude é a sua determinação afirmativa, a sua verdade em si. Assim, o finito desaparece no infinito e só esse é ( $W d L$. $I$, p. 150).

No entanto, o ser imediato do infinito desperta o seu ser negado, o finito, pois o infinito, como sendo e ao mesmo tempo como não-ser seu Outro, cai de volta na categoria do Algo com seu limite. O finito está na sua determinidade como ser-aí real diante do infinito, ficando ambos um fora do outro em relação qualitativa ( $W d L$. I, p. 151).

Finito e infinito são determinados ulteriormente como mero ser Outro contra um outro, pois a finitude é a barreira posta como barreira; é o ser-aí com a determinação posta, a qual é ultrapassar-se no seu Ser-em-si e tornar-se infinito. Esse é o nada do finito, ou melhor, seu Ser-em-si e dever, mas dentro de si refletido, como dever executado (ausgeführte) (WdL. I, p. 151). Desse modo, o infinito é carregado pela oposição do finito, que permanece como Outro, como determinado e ser-aí real, ainda que no seu Ser-em-si esteja posto o infinito como ser-suspenso. Nessa oposição, o infinito é o mau infinito (Schlecht-Unendliche), o qual vale para o entendimento como uma verdade absoluta (WdL. I, p. 152). Ambos valem, então, como duas determinidades 
ou dois mundos, um infinito e outro finito, e o infinito é posto só como limite do finito, como um determinado, como um infinito finitizado (WdL. I, p. 152). Nesses dois mundos, o finito é o ser-aí daqui, já o infinito é, ao mesmo tempo, o Ser-em-si do finito e um Além (Jenseits) turvo (trübe), inalcançável (WdL. I, p. 153).

Portanto, eles estão separados, mas essencialmente relacionados pela negação que os separa, pois essa, dentro de Algo refletida, é o limite recíproco de um frente o outro. Mas, como cada um relaciona-se afirmativamente consigo mesmo, aquele limite é negado. Ambos repelem de si o seu imediato não-ser e o põem em um ser-outro exterior a eles: o não-ser do finito é posto como infinito e esse põe o finito ( $W d L . I$, p. 153). Através de sua própria determinação, cada um põe o outro e por isso são inseparáveis, mas essa unidade está oculta na (in dem) qualidade do ser-outro, ou seja, ela é o interior que se situa só no fundo (WdL. I, p. 154). Através daí está o modo de manifestação (Erscheinung) dessa unidade determinada. Dentro do ser-aí posto está um inverter (Umschlagen) ou passar do finito ao infinito, e inversamente (umgekehrt) o passar do infinito ao finito. Evidencia-se (hervortrete) o nascimento imediato de um no outro, mas ainda como uma relação exterior ${ }^{8}$ (WdL. I, p. 154).

Nessa relação exterior, o ir além aparece como algo exterior. Assim o infinito entra no seu outro, o finito, e esse entra no infinito, mas como um acontecer exterior em que o novo limite não nasce do infinito mesmo, mas sim como se estivesse previamente encontrado (WdL. I, p. 154). Isso porque o finito é o finito só na relação com o dever, ou seja, o infinito, e esse é infinito só na relação com o finito. Essa determinação recíproca do finito e do infinito é aí-presente, um dado aí presente de antemão (vorhanden), e se apresenta (auftritt) como progresso ao infinito. Esse progresso entra onde as determinações relativas são impulsionadas até a sua oposição, estando elas em unidade inseparável, contudo atribui-se, ao mesmo tempo, a cada uma contra a outra um ser-aí independente. Daí esse progresso ser a contradição não dissolvida (aufgelöst), mas sempre tornada expressa como aí-presente (vorhanden) (WdL. I, p. 155).

Este é mau infinito, o perpétuo dever e a negação do finito, mas que ainda não se libertou desse, evidenciando-se nele mesmo como o Outro do finito, já que ele é só

\footnotetext{
${ }^{8}$ Nesse trecho da Ciência da Lógica, Hegel adianta algumas categorias próprias da Doutrina da Essência, como Grund e Erscheinung. Esses adiantamentos são freqüentes na apresentação hegeliana, sendo ulteriormente apresentados no interior do próprio trajeto lógico. Eles funcionam apenas como notas e têm um estatuto semelhante, por exemplo, ao "para nós” na Fenomenologia do Espírito.
} 
dentro dessa relação. O progresso ao infinito é, então, só a mesmidade se repetindo e a alteração enfadonha do finito e do infinito ( $W d L . I$, p. 155). No entanto, a verdade já está aí-presente nessa alternância e só é preciso (bedarf) acolher (Aufnehmens) o que está aí-presente. $\mathrm{O}$ ir para cá e para lá constitui (ausmacht) a realização externa do Conceito (WdL. I, p. 156). Assim, é preciso só saber o que diz para encontrar a determinação do finito no ( $\mathrm{im}$ ) infinito. Do finito, do seu lado, torna-se imediatamente dado que ele é nulo (Nichtige), e que, precisamente, sua nadidade (Nichtigkeit) é o infinito, do qual é, desse modo, inseparável (WdL. I, p. 157).

No entanto, ainda, o que está aí-presente é só dois finitos, pois, por um lado, o infinito está separado do finito, com isso, posto como unilateral (Einseitiges), portanto, situa-se em sua finitude unido com o finito. Por outro lado, o finito posto por si (für sich) afastado do infinito é essa relação consigo, na qual é afastada sua relatividade, dependência e transitoriedade (Vergänglichkeit), e é mesmo sua independência e afirmação, portanto, o que o infinito deveria ser (WdL. I, p. 158). Assim, ambos são um resultado que não estava na determinação do começo (Anfangs) deles (WdL. I, p. 162). Mas ambos são momentos do progresso e são em comum finitos e negados no resultado. O infinito verdadeiro é o resultado como negação da finitude de ambos (WdL. I, p. $163)$.

A diferença do verdadeiro infinito está no duplo sentido que ambos têm. Por um lado, o finito tem um duplo sentido: primeiro: só o finito está oposto ao infinito; segundo: ao mesmo tempo, estão opostos o finito e o infinito. Por outro lado, o infinito também tem um duplo sentido: primeiro: o infinito é um daqueles momentos e, assim, é o mau infinito; segundo: o infinito é de modo que aqueles, o mesmo e seu outro, são ambos só momentos. Portanto, o infinito, de fato (in der Tat), está aí-presente no processo no qual ele se rebaixa para ser só uma de suas determinações contra o finito e, com isso, ser ele mesmo só um dos finitos, e, nessa diferença sua de si mesmo, afirmar o seu suspender (aufzuheben), e, através dessa mediação, ser infinito verdadeiro (WdL. $I$, p. 163).

A determinação dessa verdade não pode ser tomada na fórmula da unidade do finito e do infinito, pois a unidade é a igualdade em si mesma abstrata, sem movimento, e os momentos são desse modo como sendo imóveis (WdL. I, pp. 163-4). O infinito é antes, essencialmente, devir, mas o devir determinado nos seus momentos seguintes, 
quais sejam, como determinação do ser e do nada, como alteração sendo-aí Algo e Outro e como infinito mesmo tornando-se finito e infinito (WdL. I, p. 164). O infinito verdadeiro é, também, ser, mas não o ser abstrato, sem determinação, e sim o serretornado-dentro-de-si (In-sich-Zurückgekehrtsein) na sua relação consigo mesmo, pois é posto como negação da negação, assim, também, como ser-aí, pois contém a negação em geral e, portanto, a determinidade. Ou seja, o infinito é e é aí, presente (präsent) e atual (gegenwärtig), diferentemente do mau infinito que é o Além, porque é só a negação do finito posto como real (WdL. I, p. 164).

O progresso ao infinito é a imagem (Bild) da linha reta, na qual o infinito é só ambos os limites e sempre só é onde a linha não é. Essa é ser-aí e vai para o não-ser-aí, para o mais além, isto é, para o indeterminado. Já o infinito verdadeiro é volta curvada dentro de si (in sich zurückgebogen), tornando a imagem do círculo a linha que se alcança e é fechada num todo atual (gegenwärtig), sem ponto de começo (Anfangspunkt) e fim (WdL. I, p. 164).

A realidade posta no finito tinha, na ocasião determinada, a negação contra o que se afirmava, mas, na verdadeira infinitude, ela é negação da negação, com isso, ela se contrapõe àquela realidade, o ser-aí finito. Por isso, a negação é determinada como idealidade (Idealität). O finito é o ideal e está dentro do infinito verdadeiro, como uma determinação contendo a diferença, mas não sendo independente, mas sim sendo momento. A idealidade tem esse significado concreto, que não estava completamente expresso na negação do ser-aí finito (WdL. I, p. 165).

Ao suspender a finitude, ou seja, a finitude como tal e desse modo também o infinito negativo, que lhe é contraposto, o ser-aí é, então, esse retorno dentro de si, a relação consigo mesmo. Aí nesse ser a negação está, ele é ser-aí, mas a negação é, além disso, essencialmente, negação da negação, negação que se relaciona consigo mesmo. Por isso, esse ser-aí é Ser-para-si (Fürsichsein) (WdL. I, p. 166).

\section{O processo de troca de mercadorias e a má infinitude da circulação}

A crítica hegeliana ao dever ser tem no seu sistema outros "capítulos", como, por exemplo, a crítica à liberdade de arbítrio, ao dever ser moral e à dinâmica da 
expansão ilimitada da produção da riqueza na sociedade civil. De maneira que a tematização do Espírito Objetivo já contém, talvez, principalmente na tematização da sociedade civil, uma "crítica ao modo de produção capitalista", ainda que não tão desenvolvida como n'O Capital de Marx. Por uma limitação externa a este trabalho, não podemos passar à tematização hegeliana do Espírito Objetivo e passaremos diretamente à tematização marxiana. Tentaremos mostrar a influência da dialética do Algo e do Outro na apresentação do processo de troca.

A riqueza na sociedade burguesa aparece (erscheint) de imediato como uma monstruosa (ungeheure) coleção de mercadorias, e a mercadoria isolada é o seu ser-aí elementar. Mas toda mercadoria se apresenta (darstellt) sob um duplo ponto de vista (doppelten Gesichtspunkt): valor-de-uso e valor-de-troca (Zur Kr., p. 107; trad., p. 57).

A mercadoria é, em primeiro lugar (zunächst), objeto de carências (Bedürfnisse) humanas. Esse ser-aí da mercadoria como valor-de-uso coincide (zusammenfallen) com sua existência (Existenz) natural palpável. Os valores-de-uso possíveis de uma mercadoria estão resumidos no seu ser-aí como coisa (Ding) com propriedades determinadas. Esses valores-de-uso são determinados qualitativamente e quantitativamente, pois, nesse último caso, diferentes (verschiedene) valores-de-uso possuem medidas diferentes (Zur Kr., pp. 107-8; trad., p. 57). No entanto, o valor-deuso, ainda que seja objeto de carências sociais e esteja num contexto social, não expressa nenhuma relação social de produção. Para a Economia Política, o valor-deuso em sua indiferença ante a determinação econômica formal situa-se além do seu círculo de observações, caindo nesse círculo apenas quando é determinação formal (Formbestimmung), ou seja, quando ele é, imediatamente, a base material na qual se apresenta uma relação econômica determinada (bestimmtes), o valor-de-troca (Zur Kr., p. 108; trad., p. 58).

O valor-de-troca aparece, em primeiro lugar (zunächst), como relação quantitativa (quantitatives Verhältnis) em que valores-de-uso são trocáveis entre si. Ele é totalmente indiferente ante o seu modo de existência (Existenzweise) natural e carência específica para a qual é valor-de-uso. Na troca, as mercadorias apresentam a mesma unidade (Einheit) (Zur Kr., p. 108; trad., p. 58). 
Essa unidade é o trabalho que se apresenta no valor-de-troca. As mercadorias são produtos da vida social, resultado da força vital (Lebenskraft) humana gasta, trabalho objetivado (Zur Kr., pp. 108-9; trad., p. 58). Os diferentes valores-de-uso são resultado de trabalhos individualmente diferentes (verschiedener), já os valores-de-troca apresentam trabalho igual, sem diferenças, trabalho abstrato universal (allgemeine) (Zur Kr., p. 109; trad., p. 59).

O trabalho universal abstrato forma (bildet) a substância do valor-de-troca. Assim como o ser-aí quantitativo do movimento é o tempo, o ser-aí quantitativo do trabalho é, analogamente, o tempo de trabalho (Zur Kr., p. 109; trad., p. 59). Esse é o "ser-aí vivo do trabalho, indiferente ante sua forma, seu conteúdo, sua individualidade; ele é o ser-aí vivo como quantidade; ao mesmo tempo (zugleich) com sua medida imanente" (Zur Kr., pp. 109-10; trad., p. 59).

A maneira e o modo (Art und Weise) específico do trabalho que põe valor-detroca, portanto, produz mercadorias, é o trabalho social. Para medir os valores-de-troca das mercadorias pelo tempo de trabalho, os diferentes trabalhos têm de ser reduzidos (reduziert) ao trabalho abstrato universal. Essa redução aparece como uma abstração executada diariamente no processo de produção social. Esse trabalho medido pelo tempo não aparece como trabalho de diferentes sujeitos (Subjekte), mas são os indivíduos diferentes que trabalham que aparecem como meros órgãos do trabalho, por isso esse trabalho poderia se expressar como trabalho humano universal (Zur Kr., p. 110 ; trad., p. 60).

Por isso, é suposto (unterstellt) que o tempo de trabalho contido numa mercadoria é tempo de trabalho necessário para sua produção, em condições universais (allgemeinen) de produção dadas (gegebenen), as quais são determinações (Bestimmungen) sociais do trabalho e uma maneira (Art) específica de sociabilidade (Zur Kr., p. 111; trad., p. 61). Assim, dentro (im) do valor-de-troca o tempo de trabalho do indivíduo aparece imediatamente como tempo de trabalho universal que se apresenta dentro de um produto universal, um equivalente universal, indiferente ante a forma determinada do valor-de-uso. O tempo de trabalho do indivíduo é seu, mas só enquanto tempo de trabalho comum (gemeine) a todos, por isso mesmo, é indiferente de qual indivíduo seja (Zur Kr., pp. 111-2; trad., p. 61). É, de fato, tempo de trabalho que a sociedade precisa (bedarf) para satisfação de uma carência determinada (Zur Kr., p. 
112; trad., p. 62). Essa comunidade (Gemeinwesen) pressuposta (vorausgesetzte) à produção impede (verhindert) que o trabalho do indivíduo seja privado, fazendo o trabalho individual aparecer imediatamente como função de um membro de um organismo social (Zur Kr., p. 113; trad., p. 63). A relação social de produção toma, então, a forma de um objeto, assim a relação (Beziehung) social das pessoas se apresenta invertida (verkehrt darstellt), a saber, como relação (Verhältnis) de Coisas (Sachen) (Zur Kr., pp. 113-4; trad., p. 63) - no entanto, dentro (im) da mercadoria essa mistificação (Mystifikation) é ainda muito simples (Zur Kr., p. 114; trad., p. 63).

Nessa relação, o valor-de-troca de qualquer mercadoria se expressa no valorde-uso de qualquer outra (Zur Kr., p. 119; trad., pp. 68-9). A mercadoria é unidade imediata de valor-de-uso e valor-de-troca, e, ao mesmo tempo, ela só é na sua relação efetiva (wirkliche Beziehung), uma sobre a outra (aufeinander), dentro do processo de troca. Por isso, valor-de-uso e valor-de-troca não podem ser considerados um de cada vez, unilateralmente. Nesse processo social, os indivíduos são independentes entre si, mas são apenas como possuidores de mercadorias, e o ser-aí recíproco de um para o outro é o ser-aí de suas mercadorias, assim eles aparecem apenas como suporte (Träger) consciente desse processo (Zur Kr., pp. 119-20; trad., p. 69).

A mercadoria é e não é, ao mesmo tempo, valor-de-uso, pois para seu possuidor ela é um não-valor-de-uso, ou seja, é um meio de troca. Como valor-de-uso, a mercadoria tem de vir-a-ser (werden) só para outros (andere). $\mathrm{O}$ vir-a-ser valor-de-uso é a suspensão (Aufhebung) do ser-aí formal da mercadoria como valor-de-uso, no qual ela era não-valor-de-uso para seus possuidores e valor-de-uso para seus nãopossuidores. O devir supõe (unterstellt), portanto, a alienação (Entäußerung) multilateral das mercadorias, ou seja, sua entrada no processo de troca. No entanto, o ser-aí das mercadorias para a troca é o seu ser-aí como valor-de-troca. Por isso, para se realizarem como valores-de-uso, têm as mercadorias de se realizar como valores-detroca (Zur Kr., pp. 120-1; trad., pp. 69-70).

Dentro do processo de troca, o valor-de-troca é atuante e não só considerado teoricamente, ou pensado. Imediatamente, a mercadoria é apenas tempo de trabalho individual objetivado com um conteúdo particular, e não tempo de trabalho universal, ou seja, ela não é imediatamente valor-de-troca, mas tem de vir-a-ser, e só pode ser objetivação de tempo de trabalho universal na aplicação (Anwendung) do tempo de 
trabalho em um fim útil, portanto, quando se apresenta dentro de um valor-de-uso. Assim, o valor-de-troca só pode se realizar afirmando-se como valor-de-uso na sua alienação (Zur Kr., p. 121; trad., p. 70). O trabalho dos indivíduos se comprovará (wird beweisen) dentro do processo de troca como trabalho social universal, através da suspensão do caráter original. Por isso, o trabalho social universal não é uma pressuposição acabada, mas sim um resultado vindo-a-ser. Assim, por um lado, as mercadorias têm de entrar no processo de troca como tempo de trabalho universal objetivado, mas, por outro lado, a objetivação do tempo de trabalho do indivíduo como universal mesmo é só um produto do processo de troca (Zur Kr., p. 123; trad., p. 72).

Essa relação, portanto, deve ser equiparação de mercadorias como materialização do tempo de trabalho universal, e, ao mesmo tempo (gleichzeitig), como relação de coisas (Dinge) qualitativamente diferentes como valores-de-uso. Essa equiparação e desequiparação se excluem mutuamente. Assim, apresenta-se não só um círculo (Zirkel) vicioso de problemas, no qual a solução de um pressupõe a solução do outro, mas um conjunto de exigências contraditórias (widersprechender), em que a satisfação (Erfüllung) de uma condição está imediatamente ligada à satisfação da condição oposta. O processo de troca, então, tem de ser tanto o desdobramento (Entfaltung) como solução dessas contradições (Zur Kr., p. 122; trad., p. 71).

Cada mercadoria deve (soll), através da alienação do seu valor-de-uso, de sua existência (Existenz) originária, portanto, obter (enthalten) sua existência correspondente como valor-de-troca. Assim, a mercadoria duplica sua existência dentro do processo de troca, pois, nesse, sua segunda existência só pode ser uma outra mercadoria (Zur Kr., p. 123; trad., p. 72).

A expressão real (reale) do valor-de-troca de uma mercadoria como equivalente universal se apresenta numa soma infinita de equações, ou seja, uma mercadoria expressa seu valor-de-troca numa soma infinita de outras mercadorias. $\mathrm{O}$ ser-aí adequado do valor-de-troca como equivalente universal é a simples inversão (Umkehrung) da série (Reihe) de equações, de modo que todas as mercadorias expressam seu valor-de-troca numa mercadoria particular, excluída como equivalente universal (Zur Kr., p. 124; trad., p. 73). Com isso, o tempo de trabalho universal se apresenta numa coisa (Ding) particular, uma mercadoria ao lado e fora de todas as outras (Zur Kr., p. 124; trad., p. 74). 
Como resultado dessa transformação (Verwandlung) de todas as outras mercadorias dentro do equivalente universal, esse se torna imediatamente objetivação do tempo de trabalho universal e a suspensão de todos os trabalhos individuais. Essa mercadoria obtém (erhält) um valor-de-uso universal, que é esse mesmo determinidade formal que vem do papel específico que ela desempenha dentro do processo de troca. Esse valor-de-uso é o mesmo para qualquer um, ser portador (Träger) de valor-de-troca, e, por isso, essa mercadoria se torna objeto de uma carência universal. Assim, dentro dessa mercadoria está "resolvida" a contradição que se encerra nas mercadorias como tais, qual seja, de ser, ao mesmo tempo, valor-de-uso particular e equivalente universal, e daí valor-de-uso para qualquer um, valor-de-uso universal. Portanto, ao passo que todas as mercadorias agora, em primeiro lugar, apresentam seus valores-de-troca como ideais (ideelle), como uma equação a se realizar, aparece junto dessa mercadoria excluída seu valor-de-uso, ainda que real (reell), dentro do processo mesmo como mero ser-aí formal, que só se realiza através da transformação no valor-de-uso efetivo (Zur Kr., p. 127; trad., p. 74).

Essa mercadoria particular, que é o ser-aí adequado do valor-de-troca de todas as mercadorias, é o dinheiro. Esse é uma cristalização do valor-de-troca das mercadorias, formada por essas mesmas dentro do processo de troca. No dinheiro, a relação social de produção aparece só mais impressionante do que na mercadoria a inversão (Verkehrung) e a mistificação real (reelle) das relações determinadas, contraídas (eingehen) dentro do processo de produção da vida social, o qual se apresenta como um objeto aí-presente (vorhanden) fora dos indivíduos (Zur Kr., p. 128; trad., p. 75). Assim, os processos de relações das mercadorias uma sobre as outras se cristalizam como determinações (Bestimmungen) diferentes do equivalente universal, e o processo de troca é, ao mesmo tempo, processo de formação (Bildungsprozess) do dinheiro. A totalidade desse processo que se apresenta como um decorrer de processos distintos é a circulação (Zur Kr., p. 130; trad., p. 77).

Esses processos de relações das mercadorias uma sobre as outras são como momentos do processo de formação do dinheiro. No entanto, o resultado é, também, começo, pois no dinheiro a inversão e a mistificação real do processo de produção 
apresentam-se vorhanden ${ }^{9}$. Como se o equivalente universal já sempre se rebaixasse como mercadoria particular que é a objetivação imediata do tempo de trabalho, e, por isso, ele não parece tornar-se dinheiro porque todas as outras mercadorias expressam nele o valor-de-troca, mas sim, inversamente, todas as mercadorias parecem expressar seus valores porque ele é dinheiro, desaparecendo o movimento mediador em seu próprio resultado. "Daí a magia do dinheiro"10. Analogamente ao infinito finitizado, o tempo de trabalho universal se apresenta numa coisa particular, numa mercadoria ao lado e fora das outras. Por isso, a relação das mercadorias no processo de troca cai no campo do dever ser, pois ambos, valor-de-uso e valor-de-troca, devem vir-a-ser dentro desse processo de troca, ambos são e não são ao mesmo tempo, tal como o dever. Por isso, ambos caem, também, na categoria do finito, pois a mercadoria é algo que tem no seu ser-dentro-de-si o valor-de-uso e o valor-de-troca, mas, ao mesmo tempo, ela só é mercadoria na sua relação efetiva com outra mercadoria, ao expressar o seu valor-detroca no valor-de-uso de outra mercadoria. A mercadoria é unidade inseparável de valor-de-uso e valor-de-troca, mas a ambas as determinações relativas são atribuídas um ser-aí independente dentro do processo de troca, mas só dentro desse a mercadoria é. Daí porque o processo de troca é processo ao infinito, em que a contradição não é dissolvida, mas sempre tornada expressa como vorhanden, em outras palavras, ele é o desdobramento e a solução dessas contradições. Assim, no dinheiro essa contradição entre a unidade e a independência do ser-aí é resolvida (gelöst), pois ele é, ao mesmo tempo, valor-de-uso particular e universal, ou seja, seu valor-de-uso é, justamente, ser portador de valor-de-troca. No entanto, nesse momento da apresentação, esse processo é

\footnotetext{
${ }^{9}$ Analogamente à dialética especulativa, na dialética materialista há um duplo movimento, ascendente e descendente. $\mathrm{O}$ ponto de vista da dialética ascendente é o da determinação progressiva do processo de formação do dinheiro. O ponto de vista da dialética descendente é o da fundação regressiva na qual o dinheiro se põe como pressuposto logicamente anterior. Na dialética especulativa do finito e do infinito, esse duplo movimento apresenta-se na imagem do círculo do infinito verdadeiro, como um todo atual sem ponto de começo e fim. Do ponto de vista da dialética ascendente, o infinito verdadeiro é resultado da determinação progressiva das categorias, no entanto, nesse resultado, ele é, ao mesmo tempo, primeiro, suspendendo as determinações finitas como momentos ideais. Cf. MÜLLER, M. L. A gênese Conceitual do Estado Ético. In: ROSENFIELD, D. et. al. Filosofia Política: nova série 2. Porto Alegre: L\&PM, 1998. pp. 9-38. p. 25. Pode-se afirmar, também, que o movimento lógico "combina pressuposição do posterior e posição do anterior". Cf. ARANTES, P. E. Hegel: a ordem do tempo. Tradução de Rubens R. Torres Filho. São Paulo: Hucitec: Polis, 2000. p. 349. Para o materialismo histórico esse duplo movimento torna-se método de apresentação progressivo-regressivo no qual a "lógica das relações sociais capitalistas funciona, assim, como um apriori interpretativo das sociedades pré-capitalistas e como fio condutor regressivo da reconstrução histórica". Cf. MÜLLER, 1982, p. 40.

${ }^{10}$ MARX, K. Das Kapital. Kritik der politischen Ökonomie. Erster Band. Buch I: Der Produktionsprozess des Kapitals. Berlim: Dietz, 2007. p. 87. Doravante citado K. I. Tradução de Regis Barbosa e Flávio R. Kothe. O Capital: Crítica da Economia Política. Livro Primeiro: O Processo de Produção do Capital. Volume I. São Paulo: Abril Cultural, 1983. (coleção Os Economistas). pp. 84-5.
} 
ainda uma relação exterior, pois a finalidade da troca ainda é externa ao movimento de circulação de mercadorias, seu impulso é aqui ainda só a satisfação de carências, pois o dinheiro ainda não se transformou em capital, e, portanto, ainda não é processo de autovalorização com finalidade em si mesmo ${ }^{11}$.

\title{
V. Restituir a linguagem ao pensamento livre
}

\begin{abstract}
A liberdade nos é devolvida para trabalharmos sobre os textos e brincar com os seus conteúdos, sem que tenhamos de nos pôr atenciosamente à escuta. Por sua vez, um filósofo não propõe nem ruptura nem evasão nem conversão, nada que se pareça com as grandes decisões nas quais o que está em jogo é sua felicidade. Não há nada senão uma maré montante que recobre as significações 'bem conhecidas', nada mais que um discurso sem pressa que não constitui senão a si mesmo ${ }^{12}$.
\end{abstract}

Até aqui apresentamos, em linhas gerais, de um lado, a dialética hegeliana do Algo e do Outro. Vimos que o limite é imanente ao Algo e é sua contradição mesma. Isso nos levou, por fim, a tematizar a dialética do finito e do infinito. Do outro lado, tentamos aproximar essa dialética do Algo e do Outro com o processo de formação do dinheiro na apresentação marxiana. No entanto, ficamos apenas numa comparação exterior. Neste último item, talvez, seja importante tentar indicar o ponto de vista comum entre essas duas dialéticas para não ficarmos somente numa analogia. A hipótese, como já foi mostrada na introdução, é de que a "dessublimação da filosofia" operada por Marx não é estranha à Lógica hegeliana, estando em curso no seu próprio projeto sistêmico. Dessa maneira, talvez seja importante, antes, esboçar uma reflexão

\footnotetext{
${ }^{11}$ Segundo J. Grespan: “(...) a valorização do valor, que constitui o capital, é não só valorização de si, mas também por si; é autovalorização. O que na circulação simples aparecia como 'substância' cujo movimento não determina por si suas formas, passa a ser 'uma substância processante, se-movente' [K. I, p. 169; trad., p. 13]; ou seja, determinação de seu movimento unicamente por si enquanto finalidade de si. Em outras palavras, 'sujeito', na acepção exposta acima". Cf. GRESPAN, J. L. S. O negativo do Capital: O Conceito de Crise na Crítica de Marx à Economia Política. São Paulo: Hucitec: Fapesp, 1999. p. 124.

${ }^{12}$ LEBRUN, G. A paciência do Conceito: ensaio sobre o discurso hegeliano. Tradução de Silvio Rosa Filho. São Paulo: UNESP, 2006. p. 409.
} 
sobre o "discurso dialético", pois localizar o seu tempo parece ser importante para compreender o significado da noção dialética de contradição.

No Prefácio à Ciência da Lógica de 1812, Hegel afirma, fazendo um diagnóstico sobre a situação do pensamento metafísico, que a "doutrina exotérica kantiana (...) justificou pelo lado científico a renúncia ao pensamento especulativo”. Ao afirmar que "ao entendimento não se permite sobrevoar a experiência, senão a faculdade do conhecimento torna-se razão teorética, a qual por si dá à luz como quimera (Hirngespinste)", essa "doutrina popular" foi de encontro ao alarido (Geschrei) da moderna pedagogia, a necessidade (Not) dos tempos, que dirige o olhar para a carência imediata. Trabalhando de mãos dadas, ciência e entendimento humano comum efetuaram o naufrágio da metafísica, tornando, então, aparentemente produzido o espetáculo espantoso de se ver "um povo cultivado sem metafísica" (WdL. I, pp. 13-4).

A lógica não estava numa situação tão ruim como a metafísica, pois ela tinha ainda um lugar entre as ciências e era, inclusive, objeto do ensino público. No entanto, o "novo espírito" que abriu a ciência, não menos do que a efetividade, ainda não se deixou sentir (verspüren) na lógica (WdL. I, pp. 14-5). A ciência lógica que constitui a metafísica propriamente ou a filosofia especulativa viu-se, então, negligenciada ( $W d L$. $I$, p. 16).

A tarefa da Ciência da Lógica consiste, então, em trazer à consciência a natureza lógica que anima esse novo espírito, ou seja, em purificar e elevar à liberdade e à verdade as categorias que, isoladas, em primeiro lugar, são atuantes (wirksam) só instintivamente como impulsos; e são trazidas à consciência do espírito de maneira emaranhada e variável, apenas com uma garantia efetiva isolada e insegura. Por isso, esse agir (tun) instintivo distingue-se, em geral, do agir inteligente e livre que acontece com consciência. Assim, a liberdade do espírito começa quando o conteúdo que o impulsiona é trazido para fora da unidade imediata do sujeito, como objetividade diante dele (WdL. I, p. 27).

Ao considerar as determinações-do-pensar (Denkbestimmungen) só como formas exteriores, a saber, nelas mesmas, só se pode provir (hervorgehen) a sua finitude e não-verdade do seu dever-ser-por-si, e, como sua verdade, o Conceito. Assim, tal consideração torna-se ciência lógica. Essa é reconstrução (Rekonstruktion) das 
determinações-do-pensar que são acentuadas através da reflexão e por essa fixadas como formas subjetivas exteriores à matéria e ao conteúdo (Gehalt). A ciência lógica trata, também, daquelas determinações-do-pensar que atravessam, em geral, nosso espírito intuitivamente e sem consciência (bewußtlos), e mesmo quando essas entram na linguagem e passam despercebidas e inobjetivamente (ungegenständlich) (WdL. I, p. 30). Essas formas-do-pensar na sua objetividade é o conteúdo (Inhalt) da lógica, mas não como coisa (Ding), mas sim como Coisa (Sache) na sua interioridade substancial, em outras palavras, "o conceito das coisas (Dinge), que se torna objeto" (WdL. I, p. 29). A lógica, então, contém o pensamento como Coisa em si mesmo (Sache an sich selbst) (WdL. I, p. 43). Ela contém só o pensamento puro como determinações objetivas, sem introduzir nada exterior, e, por isso, seu método não é distinto (Unterschiedenes) do seu objeto e conteúdo: "ele é o conteúdo em si, a Dialética que ele tem nele mesmo, na qual ele avança (fortbewegt)"13 (WdL. I, p. 50). Por isso, a apresentação (Darstellung) vai ao passo desse método, ou seja, segundo seu ritmo simples, pois ela é o passo da Coisa mesma (WdL. I, p. 50).

Essa lógica objetiva toma a posição da antiga metafísica, enquanto essa era o edifício científico sobre o mundo, que deveria ser construído só através do pensamento. Mas conceitua dentro de si, também, o resto de metafísica que tomava as formas puras do pensamento, particularmente, em primeiro lugar na representação (Vorstellung) denominada substratos: Alma, Mundo e Deus; os quais procuravam constituir as determinações do pensamento do modo de consideração do essencial. No entanto, esta lógica se considera livre desses substratos, ou sujeito da representação, e é essencialmente crítica, pois examina (Untersuchung) se aquelas formas são capazes (fähig) de ser determinações da coisa-em-si, ou seja, determinações do pensamento puro. Ela é a verdadeira crítica porque considera essas determinações mesmas em seu conteúdo particular, sem as formas abstratas a priori ante o a posteriori. Essa lógica torna-se subjetiva, isto é, lógica do Conceito, como essência que suspendeu sua relação com um ser ou sua aparência, e que dentro da sua determinação não é mais exterior, mas

\footnotetext{
13 “A única maneira (Das Einzige) para conquistar (gewinnen) a continuação (Fortgang) da ciência - e é essencial para se conseguir essa intelecção (Einsicht) totalmente simples - é o conhecimento das proposições lógicas de que o negativo é tão muito positivo, ou que se contradizendo não se dissolve no nulo, no nada abstrato, mas só essencialmente na negação do seu conteúdo particular (besonderen), ou que numa tal não é toda negação, mas sim que a negação é da Coisa determinada, que se dissolve (auflöst), assim é negação determinada" (WdL. I, p. 49).
} 
sim livre e independente como sujeito se determinando dentro de si mesmo ( $W d L$. $I$, pp. 60-1).

Nesse sujeito, que conceituou as formas-do-pensar depositadas na linguagem comum, que criticou verdadeiramente toda a metafísica anterior, e que é, por isso, livre e independente, determinando-se dentro de si mesmo, G. Lebrun concebeu aí a criação de uma "nova linguagem", na qual "os discursos emitidos na antiga linguagem podem ser situados e reconhecidos". Assim, a especulação não seria uma "nova doutrina", já que "não há substituição do que deveria ser dito pelo que foi efetivamente dito, mas substituição de uma gramática por outra, de um jogo de linguagem por outro" (LEBRUN, 2006, p. 94). Nada seria, então, mais “decepcionante" que a "desmistificação hegeliana": "essa lenta alteração que parece metamorfosear as palavras que empregamos no início, sem que no entanto devêssemos renunciar a elas ou inventar outras, esse é o sentido mesmo, enfim despojado de sua finitude" (LEBRUN, 2006, p. 118). Ou seja, é decepcionante porque "tudo estava dito, e bastava saber ler; ainda era preciso, porém, saber que tudo era dizer" (LEBRUN, 2006, p. 118). Desse modo, a própria palavra "filosofia" sofre uma "mutação radical", pois nos atamos às teses filosóficas tão-só para, “por intermédio delas, tornar patentes as regras de um jogo que todos os sistemas jogavam à sua revelia. Diante disso, a filosofia que põe a negatividade em elaboração é a primeira filosofia a funcionar explicitamente como um discurso que põe suas cartas na mesa" (LEBRUN, 2006, p. 318). Como é só "por intermédio delas", não há um princípio dado, e por isso Entwicklung é tão-só atividade do Conceito, e não “um desenrolar contínuo nem um progressus temporal” (LEBRUN, 2006, pp. 352-3). A "crítica" seria então o "desnudamento de opções inconscientes que até então falseavam o livre jogo do discurso" (LEBRUN, 2006, p. 203). Daí a diferença entre o "representativo" e o "especulativo". O primeiro, na tentativa de "descrever" as "coisas representáveis" "sempre abandona cedo de mais o questionamento dos conteúdos", passando, assim, "cedo de mais ao concreto" (LEBRUN, 2006, p. 407). Já a especulação "deixa de formar a trama de um conhecimento-de-coisas. Ela se torna Saber, isto é, tomada de consciência pela filosofia de que ela é, de ponta a ponta, linguagem” (LEBRUN, 2006, p. 402). Daí porque, no lugar de um "dogmatismo", há um "positivismo hegeliano": "uma aposta de neutralidade, a convicção de que uma linguagem pode ser decapada de toda ontologia e as regras lógico-ontológicas (...) podem ser tratadas, por sua vez, como significações a serem explicitadas" (LEBRUN, 
2006, p. 205). Assim, "a linguagem reencontra sua função de negação do imediato", e os conteúdos estáveis se dissolvem (LEBRUN, 2006, p. 208). Ao "pensamento não finito, isto é, ontologicamente neutro (...) não há conteúdo que não se possa repor no circuito da linguagem" (LEBRUN, 2006, p. 206). A linguagem, então, não tem mais sua verdade fora dela (LEBRUN, 2006, p. 214), e o método do saber "é um recolhimento da linguagem sobre si" (LEBRUN, 2006, p. 405), portanto: "Se as palavras são vazias, é porque ainda não sabemos pensar dentro delas" (LEBRUN, 2006, p. 214).

Nessa "nova linguagem" liberada do "conhecimento-de-coisas", "o movimento do Conceito não é, de maneira alguma, o análogo de um processo de conhecimento", pois haveria uma "indiferença do conceitual ao histórico". Assim, a exposição conceitual "não pretende concorrer com a ordem temporal, ela não descreve uma gênese que conferiria um sentido às determinações, às avessas da ordem de aparecimento destas últimas" (LEBRUN, 2006, p. 350). No entanto, de fato, se a apresentação conceitual não concorre com a ordem temporal histórica é, justamente, porque ela apresenta a gênese que confere um sentido às determinações, às avessas da ordem de aparecimento destas últimas. Se a atividade do Conceito não é "progressus temporal" é porque a "potência do tempo" só se exerce sobre o finito, pois, conforme vimos, esse progresso era progresso ao infinito, no qual o infinito era só o não-ser-aí do ser-aí da linha reta, e, por isso, ele era só ambos os limites da linha. O infinito era, assim, finito, porque limitado, e o finito era o que o infinito deveria ser, pois o finito era finito só na sua relação com o seu dever, o infinito, seu limite como determinação em-si, posto como barreira, e, por isso, ele era relação consigo mesmo, ou seja, sua afirmação e independência. Ambos eram momentos do progresso e, em comum, finitos negados no seu resultado, como infinito finitizado e finito infinitizado. A infinitude verdadeira foi, então, o resultado da negação da finitude de ambos. Nesse resultado, o infinito é vorhanden, através do processo no qual ele se rebaixa e se suspende, sendo através dessa mediação infinito verdadeiro. Era só preciso saber o que diz para encontrar, no progresso ao infinito, a determinação do finito e do infinito e aí a realização externa do Conceito, mas esse saber não é um dado imediato. Ao conceber o Conceito como indiferente ao histórico, Lebrun deixa de dar atenção à ordem lógica interna do Conceito que está, justamente, numa relação inversa com a ordem histórica: "o que vem primeiro na verdade é reencontrado ao termo da derivação conceitual, como resultado: há, pois, um retorno que faz com que o imediato se encontre posto segundo seu ser verdadeiro" 
(ARANTES, 2000, p. 349). Sim, não se pode confundir fundamento com existência real, princípio conceitual e histórico, mas ordem lógica e série temporal acabam se entrecruzando, mais especificamente, isso é resultado do "teor especulativo da noção de fundamento e ao fato de que a relação de ordem contém uma determinação teleológica dentro de si", isto é, o fundamento é retorno a si, é "círculo de fundamento" que responde, assim, ao "círculo especulativo", em outras palavras, "o fundamento é concomitante primeiro e derivado, originário e posto" (ARANTES, 2000, p. 350).

O risco de aceitar completamente essa indiferença do conceitual ao histórico é, talvez, cair na "relação negativa infinita" do processo de diferenciação interna da identidade do $\mathrm{Eu}=\mathrm{Eu}$, através do qual, longe de ser totalmente indiferente, a negatividade do tempo é sua expressão ${ }^{14}$. Essa "nova linguagem" designaria tão somente a Urteil, a cisão original do Espírito que se torna "eu, livre subjetividade em face da determinidade" (ARANTES, 2000, pp. 159-60), mas essa "co-pertinência, tanto ontológica quanto formal, do $\mathrm{Si}$ e do tempo não dá lugar a nenhuma relação de fundação, não resulta nenhuma operação constitutiva" (ARANTES, 2000, p. 163). Em outras palavras, não há um processo mediador que põe o infinito verdadeiro, esse é tomado apenas unilateralmente no seu resultado em que o processo mesmo desaparece. De fato, o que desaparece mesmo é, então, a Bildung que, em sua determinação absoluta, é "a liberação e o trabalho de liberação superior, o ponto de passagem absoluto em direção à substancialidade infinita subjetiva da esfera ética" (HEGEL, Grundlinien der Philosophie des Rechts, § 187, pp. 168-9, apud ARANTES, 2000, p. 255). De fato, a indiferença em relação ao tempo é o resultado de um trabalho de formação que muda o registro do Espírito com o tempo: "é como se, no próprio coração de sua necessária manifestação temporal, o Espírito contemplasse de cima o tempo de seu trabalho, como se esse tempo se tivesse tornado, para ele, como que indiferente". (ARANTES, 2000, p. 286, grifo nosso). Isso ilustra o procedimento hegeliano e mostra como ele está em sintonia com seu tempo: "tornar possível um ponto de vista atemporal respaldado em um tempo histórico apreendido com o auxílio do conceito de trabalho" 15 (ARANTES, 2000, p. 286).

\footnotetext{
14 “Assim, temporalidade e pensamento discursivo têm uma proveniência comum, desenrolando-se sobre o mesmo fundo de dualidade, explicam-se por uma mesma cisão, por uma Spaltung da ipseidade" (ARANTES, 2000, p. 161).

${ }^{15}$ Ainda segundo P. Arantes, o jovem Marx foi quem pôs a nu esse ponto de vista: “O jovem Marx, por sinal, já sublinhava aquilo que permanecia invariante no bojo mesmo dessa reversão quando, após haver
} 
A filosofia hegeliana, então, está respaldada em um tempo histórico. Daí porque "não seria injusto definir o interesse supremo da filosofia (...) pela noção de reconciliação com o Presente", ou seja, a filosofia "capta seu tempo no pensamento" (ARANTES, 2000, p. 313). Mas, com isso, "o próprio tempo é eterno em seu conceito" (ARANTES, 2000, p. 181). Assim, conforme vimos, a tarefa da lógica consiste em trazer a natureza lógica que anima o novo espírito. Ao suspender o progresso ao infinito, o infinito verdadeiro se apresentou como o que é e é aí, presente (präsent) e atual (gegenwärtig).

Essa filosofia, respaldada em um tempo histórico apreendido com o auxílio do conceito de trabalho, pode, então, para a dialética materialista, antecipar ${ }^{16}$ estruturas racionais de algumas dimensões econômicas fundamentais da sociedade burguesa dominada pela relação capitalista (MÜLLER, 1982, p. 31). A dialética especulativa pode, então, transformar-se em "método de apresentação" que "reconstrói" "discursivamente (enquanto procedimento do expositor) a lógica objetiva do material", mas é "procedimento" que "expressa, reproduz, apenas (tão só e cabalmente), em conformidade com a apropriação analítica, o 'movimento efetivo' do material, de modo que este se 'espelhe idealmente' no método" (MÜLLER, 1982, p. 22). Por isso, esse “espelhamento (Widerspiegelung)" só pode ser compreendido a partir da sua origem na dialética especulativa, pois ele nada mais é do que a apresentação da "lógica objetiva e própria da coisa sem interferências subjetivas prévias do analista e externas ao movimento do conceito da coisa" (MÜLLER, 1982, p. 36).

No entanto, o movimento do conceito da coisa não é mais, na dialética materialista, o conceito de sujeito como auto-relação de uma atividade pura e absoluta, mas sim "de um substrato, o valor, que na sua relação consigo se torna processo de autovalorização do capital” (MÜLLER, 1982, p. 31). Essa mudança de significado do movimento da Coisa mesma na dialética materialista é não só resultado de uma

posto a nu o ponto de vista hegeliano, que é o mesmo ponto de vista da economia política moderna, fazia observar que 'o único trabalho que Hegel conhece e reconhece é o trabalho abstrato do espírito"” (ARANTES, 2000, p. 287).

16 “Tal como o procedimento do saber: a filosofia não é desprovida de toda faculdade de antecipação. Basta lembrar os textos célebres da Fenomenologia em que, após ter observado que não é difícil ver que 'nosso tempo é um tempo de gestação e transição para um novo período', Hegel se refere aos 'signos anunciadores de algo outro que está em marcha'. 'Esse contínuo esmigalhamento que não alterava a fisionomia do Todo é bruscamente interrompido pelo nascer do sol que, num clarão, desenha de uma vez a forma do novo mundo' (p. 15-6; trad. I, p. 12)" (ARANTES, 2000, pp. 332-3, grifos nossos). 
inversão, já realizada pela dialética hegeliana, mas também um "virar do avesso (umstülpen)":

\begin{abstract}
Virando ao avesso a realidade invertida, alienada pelo capital, "enquanto figura objetiva consumada da propriedade privada' [MARX, FS., p. 589], $a$ contradição, que estava do lado de fora, transforma-se no verdadeiro interior, na pérola racional desta realidade, e o que estava dentro, a unidade resolutiva e integradora das contradições, revela-se como o seu exterior aparente, o seu envoltório não só místico, mas mistificador (MÜLLER, 1982, p. 26, grifos nossos).
\end{abstract}

Essa Umstülpung revela, então, uma determinada continuidade entre a crítica do jovem Marx ao idealismo e a perspectiva da Crítica da Economia Política, qual seja, a "crítica ao duplo aspecto mistificador do idealismo": o "aspecto positivista": "o existente, transfigurado pela especulação, é assumido acriticamente e ratificado em sua positividade pelo sistema"; o "aspecto especulativo": a "resolução harmonizante das contradições numa unidade essencial, que se torna para Marx aparente, ideológica" (MÜLLER, 1982, p. 26). No entanto, nesse segundo aspecto, a crítica marxiana é não só crítica ao idealismo, mas também da aparência ideológica do sistema capitalista. Assim, no dinheiro, conforme vimos, a relação social de produção aparece como inversão e mistificação real das relações determinadas. Daí porque, talvez, deixa de ser objeto da crítica marxiana o "o núcleo do misticismo hegeliano"17, pois esse se torna dentro da Crítica da Economia Política inversão e mistificação real do processo de produção da vida social, que se apresenta como objeto vorhanden fora dos indivíduos. Em outras palavras, não estaria aqui a "solução enigmática da desenvoltura ontológica do Conceito?"

\footnotetext{
${ }^{17}$ É isso que a abordagem de Giannotti não parece querer levar em consideração: "Não reside aqui o núcleo do misticismo hegeliano, tantas vezes denunciado por Engels e Marx? Mas sem esse misticismo lógico não há como imaginar que a proposição constitui o caso da identidade da identidade e da diferença" (GIANNOTTI, 2000a, p. 65). Como bem salientou R. Fausto, o "misticismo na dialética hegeliana" é reabilitado n'O Capital como determinação do objeto. Cf. FAUSTO, R. Le Capital et la Logique de Hegel: dialectique marxienne, dialectique hégélienne. Paris: L'Harmattan, 1997. p. 118.
} 


\section{Conclusão}

Neste trabalho tentamos apresentar o significado da noção dialética de contradição no capítulo "O Ser-aí" da Ciência da Lógica de Hegel e no capítulo "A Mercadoria" de Para a Crítica da Economia Política de Marx. Em seguida, tentamos aproximar o ponto de vista das duas dialéticas, apontando para um "respaldo histórico" que possui a dialética hegeliana.

Vimos, por um lado, que o Ser-dentro-de-si do Algo contém a negação dentro de si, o Ser-outro. Algo tem, portanto, o Outro dentro de si, mas, ao mesmo tempo, Algo e Outro estão separados. O limite é, então, determinidade do Algo, sua contradição mesma que o dirige para fora e o impulsiona. O progresso ao infinito se apresentou como a imagem da linha reta na qual essa contradição não é dissolvida, mas tornada sempre aí-presente. Ele entra onde as determinações relativas são impulsionadas até a sua oposição, estando em unidade inseparável, mas, ao mesmo tempo, tendo cada uma delas, uma contra a outra, um ser-aí independente.

Por outro lado, vimos que, no processo de troca, as determinações relativas da mercadoria, valor-de-uso e valor-de-troca, são impulsionadas até a sua oposição. A mercadoria é unidade imediata de valor-de-uso e valor-de-troca, mas, no processo de troca, sua existência é duplicada, pois o valor-de-troca de uma mercadoria se expressa no valor-de-uso de outra mercadoria. Para se realizarem como valores-de-uso, têm as mercadorias de se realizar como valores-de-troca, mas, ao mesmo tempo, para realizarem os seus valores-de-troca, têm as mercadorias de se comprovar como valoresde-uso. Apresenta-se assim um conjunto de exigências contraditórias em que a satisfação de uma condição está imediatamente ligada a satisfação da condição oposta. Isso porque, assim como no progresso ao infinito, as determinações opositivas, portanto, em unidade inseparável, têm, ao mesmo tempo, um ser-aí independente.

$\mathrm{Na}$ dialética hegeliana, essa contradição se dissolve no infinito verdadeiro, resultado da dupla negação do infinito finitizado e do finito infinitizado. O finito e o mau infinito se tornam momentos ideais da infinitude verdadeira. Na dialética materialista, o dinheiro "resolve" a contradição que encerra nas mercadorias, pois seu valor-de-uso é, justamente, ser portador do valor-de-troca. No entanto, posteriormente, no processo de circulação, essa duplicação da mercadoria em mercadoria e dinheiro não 
será a suspensão das contradições, mas a forma dentro da qual elas podem se mover (cf. K. I, p. 118; trad., p. 93). Na dialética materialista, a infinitude lógica do capital só poderá ser posta quando o capital incluir a força de trabalho como momento seu, como capital variável, assim tornando-se "sujeito" que se valoriza por si (cf. GRESPAN, 1999, p. 125).

A comparação entre a dialética do ser-aí e da mercadoria nos possibilita identificar que em ambas a contradição não é um dado imediato, mas sim o resultado do pensamento que adentrou nas determinações do ser-aí. Pensamento que se transforma em método de apresentação da contradição interna da mercadoria, pois, como vimos, essa, imediatamente, era só coisa (Ding), objeto de carências humanas. A contradição é, portanto, efetiva, "wirkliche Widersprüche" 18 , no sentido que dá a dialética hegeliana à efetividade como unidade do interior e do exterior ${ }^{19}$.

O processo de troca tem que ser, então, tanto o desdobramento como solução das contradições. O dinheiro apresentou-se como resultado desse processo, que se torna processo de formação do dinheiro. No seu resultado o dinheiro é, ao mesmo tempo, primeiro, pois nele os processos de relações das mercadorias se cristalizam como determinações diferentes dele. Tal como o infinito verdadeiro que no seu resultado é sem ponto de começo e fim. Vimos que Lebrun, ao conceber o Conceito como indiferente ao histórico, deixa de dar atenção ao tempo lógico interno do Conceito, ao movimento ascendente e descendente da dialética. A paciência do Conceito torna-se não o trabalho da Bildung, mas simples relação negativa infinita que resulta da dualidade entre temporalidade e pensamento discursivo mantido na sua indiferença com o tempo.

O Absoluto concebido por Lebrun como simples "recolhimento da linguagem sobre si" é a concepção que tem Giannotti da lógica hegeliana. A "mistificação hegeliana" é, então, para ele, esse recolhimento da linguagem sobre si, que teria sido alvo da critica do jovem Marx, e não a determinação da Coisa mesma. Uma outra linguagem não mistificadora capaz ler a contradição foi buscada, então, nos "jogos de linguagem não verbal”, nos quais, para ele, "a forma de sociabilidade posta pelo capital

\footnotetext{
${ }^{18}$ Cf. K. I, p. 118; trad., p. 93.

${ }^{19}$ Cf. ARANTES, 2000, pp. 330-1. M. Müller resume assim um erro comum entre os marxistas: "O verdadeiro concreto, que era, para Marx, o resultado de sua reconstrução sintética no pensamento, tende a ser confundido com uma imediaticidade factual, com o 'concreto empírico e imediato' de Marx, e a dialética como método parece reduzir-se à duplicação de uma dialética dos fatos sem pensamento, e no caso de Hegel, a uma 'construção abstrata' contraposta a positividade dos fatos” (MÜLLER, 1982, p. 37).
} 
é estudada por si mesma, não derivando nenhuma outra que pudesse desvendar o seu sentido oculto" ${ }^{20}$. Evidentemente, não cabe aqui uma análise mais detalhada desse ponto de vista, mas convém só perguntar se por trás desse “jogo de linguagem não verbal” não permanece um sujeito da representação que determina se a contrariedade é ou não contradição? Sendo a passagem de uma relação social a outra sempre esse jogo, não se incorre no risco de transformar o perecer em imperecível? A apresentação dialética, como o passo da Coisa mesma, não incorre nesse risco.

Era Smailes porque a voz do professor me chegava clara $(\ldots)^{21}$

VII. Bibliografia

ARANTES, P. E. Um Departamento francês de ultramar: Estudos sobre a formação da cultura filosófica uspiana (Uma experiência nos anos 60). São Paulo: Paz e Terra, 1994.

. Hegel: a ordem do tempo. Tradução de Rubens R. Torres Filho. São Paulo: Hucitec: Polis, 2000.

FAUSTO, R. Le Capital et la Logique de Hegel: dialectique marxienne, dialectique hégélienne. Paris: L’Harmattan, 1997.

GIANNOTTI, J. A. Dialética futurista e outras demãos. Novos Estudos CEBRAP, São Paulo, n. 57, pp. 59-79, Jul. 2000a. Disponível em: 〈http://novosestudos.uol.com.br>. Acesso em: 4 jan. 2008.

Certa herança marxista. São Paulo: Companhia das Letras, 2000b.

GRESPAN, J. L. S. O negativo do Capital: O Conceito de Crise na Crítica de Marx à Economia Política. São Paulo: Hucitec: Fapesp, 1999.

\footnotetext{
${ }^{20}$ GIANNOTTI, J. A. Certa herança marxista. São Paulo: Companhia das Letras, 2000b. p. 129.

${ }^{21}$ Cf. Infância, op. cit., p. 176.
} 
HEGEL, G. W. F. Wissenschaft der Logik I. Erster Teil: Die objektive Logik. Erstes Buch. Werke in zwanzig Bänden. Edição de E. Moldenhauer e K. M. Michel. Frankfurt am Main: Suhrkamp, 1986. v. 5.

Enzyklopädie der philosophischen Wissenschaften im Grundrisse (1830).

Erster Teil: Die Wissenschaft der Logik mit den mündlichen Zusätzen. Werke in zwanzig Bänden. Edição de E. Moldenhauer e K. M. Michel. Frankfurt am Main: Suhrkamp, 1986. v. 8.

LEBRUN, G. A paciência do Conceito: ensaio sobre o discurso hegeliano. Tradução de Silvio Rosa Filho. São Paulo: UNESP, 2006.

MARX, K. Zur Kritik der Politischen Ökonomie. Karl Marx Friedrich Engels Gesamtausgabe (MEGA). Zweite Abteilung, Band 2. Berlim: Dietz, 1980. pp. 95-245.

Das Kapital. Kritik der politischen Ökonomie. Erster Band. Buch I: Der Produktionsprozess des Kapitals. Berlim: Dietz, 2007.

MÜLLER, M. L. Exposição e método dialético em 'O Capital'. Boletim SEAF (Sociedade de Estudos e Atividades Filosóficas). Belo Horizonte, n. 2, pp. 17-41, 1982. A gênese Conceitual do Estado Ético. In: ROSENFIELD, D. et. al. Filosofia Política: nova série 2. Porto Alegre: L\&PM, 1998. pp. 9-38. 